\title{
POLITICALLY CORRECT HATE SPEECH
}

The purpose of this paper is to present a brief discussion of selected aspects of incriminating hate speech in Poland, first focusing on how the perception of speech acts and the rules of precaution adopted in Polish society in this regard translate into criminal lability for hate speech, and then on the effectiveness of both the penal measures and the attempted European harmonization in this area. Within the scope of such a short report it is of course not possible to touch on all the hate speech issues associated with criminal law. Presenting an in-depth study on this topic would require a separate monograph and empirical case research on the application of current penal provisions in what could be qualified as 'hate speech cases'. Such a study could support or challenge the presumption that this application is far from satisfactory. The aim of the following short article is to present some explanations for, and aspects of, the problems that might arise in the context of criminalizing the special form of human behaviour that is constituted by speech, rather than action, ${ }^{1}$ and which might emerge in the process of executing the relevant provisions; and to consider how attitudes in society towards what can be expressed and what can be said translate into criminal liability.

Before going into details, some preliminary points require clarification. First of all, the term 'hate speech' is not used in Polish law, and it lacks a legal definition. It is relatively new to the Polish doctrine of criminal law but is quite often used in public debate and in numerous non-juridical contexts. The non-juridical definitions are subsequently quoted by both courts and scholars. Thus, though it still seldom appears in the commentaries to the Criminal Code, 'hate speech' becomes a term rooted in the judicial language and is more and more present in jurisprudence.

Secondly, obviously the phenomenon of hate speech has a significantly broader context than just the legal one, hence we differentiate between acts of hate speech as such (the use of language of contempt, disdain and scorn), and the crime of hate speech. Analogously, we separate 'hate crime' from 'hate incidents' (which are not crimes). Hate speech in the broad sense is understood as any statement present in the public sphere which is insulting and/or degrading, or the content of which content incites hatred towards someone because of their belonging to a specific group (for example

${ }^{1}$ On the differences between speech and action see, e.g. Schauer (2015): 427-454. 
sexual minorities). In a narrow sense, it is speech penalized by criminal sanctions. ${ }^{2}$

In the Polish Criminal Code (CC), there are several provisions that deal with various forms of language of contempt. The most important in this regard are: Article $256 \mathrm{CC}$, according to which anyone who publicly incites hatred based on national, ethnic, race or religious differences, or for not being religious, is liable to punishment; and Article $257 \mathrm{CC}$, which prohibits 'public insult to a group of people or a particular person because of their national, ethnic, racial, religious affiliation or because of their lack of religion.' However, Articles $119,{ }^{3} 126 \mathrm{a},{ }^{4}$ and $255^{5} \mathrm{CC}$ are also worth mentioning.

With regard to their wording, the relevant regulations seem to comply with the European standards and guarantee the scope of criminal protection against the 'words that wound' desired by the European legislator. This may lead us to the conclusion that Polish legislation meets the obligations resulting from the Council Framework Decision on combating certain forms and expressions of racism and xenophobia by means of criminal law 2008/913/JHA of 28 November 2008. But the observation of public and private life and disputes, supported by various reports and statistics, shows that this compliance is to a certain extent illusory. And this, as we shall see, is not necessarily our fault.

The cited framework decision sets out the common rules for combating racist and xenophobic offences in all Member States by means of criminal law. Its purpose is to define 'a common criminal law approach in the European Union to the phenomenon of racism and xenophobia, in order to ensure that the same behaviour constitutes an offence in all Member States.' It is an instrument similar to, for example, the Framework Decision on combating corruption in the private sector, the directives on the protection of the euro and other currencies, and on the protection of the environment through criminal law. But what makes it special and difficult to apply is the nature of the behaviour it is aimed at restricting, namely certain forms of speech.

The particularity of human expression as a behaviour being subject to criminal evaluation implies that divergent views are held by society and the judicial authorities of different Member States with regard to determining

${ }^{2}$ E.g. Rogalska, Urbańczyk (2017): 119-120; Other definitions can be found in: Kowalski, Tulli (2001); Łodziński (2003): 5; Gliszczyńska, Sękowska-Kozłowska, Wieruszewski (2007); Czykwin (2007): 375.

${ }^{3}$ Article 119 CC: ‘ $\$ 1$. Whoever uses force or an unlawful threat towards a group of people or an individual person because of their national, ethnic, racial, political or religious affiliation or lack of religious affiliation, is subject to the penalty of deprivation of liberty for between 3 months and 5 years.'

${ }^{4}$ Article 126a CC: 'Whoever publicly incites others to commit the act provided for in arts. $118,118 \mathrm{a}, 119 \S 1$, arts. $120-125$ or publicly extols the commission of the act provided for in those provisions, is subject to the penalty of deprivation of liberty for between 3 months and 5 years.'

${ }^{5}$ Article $255 \S 1 \mathrm{CC}$ : 'Whoever publicly incites others to commit a misdemeanour or a fiscal crime, is subject to a fine, the penalty of limitation of liberty or the penalty of deprivation of liberty for up to 2 years. $\S 2$. Whoever publicly incites others to commit a felony, is subject to the penalty of deprivation of liberty for up to 3 years. $\S 3$. Whoever publicly exhorts the commission of a crime, is subject to a fine in the amount of up to 180 daily rates, the penalty of limitation of liberty or the penalty of deprivation of liberty for up to one year.' 
what acts can be qualified as expressing something that can be classified as incitement or hatred and, in turn, which acts can constitute a crime. ${ }^{6}$ Currently, it does not seem possible, or is extremely difficult, to guarantee the same scope of incrimination and safeguard a similar level of protection against hate speech in the multicultural environment of the EU. Irrespective of any attempts at legal harmonization, the same speech act can and will be legally evaluated differently in the different cultural contexts of various EU countries, not necessary in the way envisioned by the European legislator.

The divergences originate in the very nature of speech and in what we consider criminal behaviour - that is, behaviour requiring a sanction and repression that satisfies the common sense of justice. In the Polish criminal law system, a crime is constituted by five elements: an act that is prohibited by the law in force at the time of its perpetration; and that is unlawful, socially harmful and culpable. ${ }^{7}$ The core of this structure is the prohibited act, that is, an act of a natural person, whose features, objective and subjective character traits, have been defined by the law. ${ }^{8}$ In this context it is, of course, crucial to determine what an 'act' is, in terms of what part of human behaviour constitutes a separate unit that can undergo criminal evaluation. There are of course various theories on this issue, and the problem remains largely unsolved: it is still difficult to speak of a persuasive opinion that could be treated as prevailing.

However, what is important for our deliberations is that in recent years legal scholars, and the courts to some extent, have brought into focus an additional, special criterion for considering a human act as prohibited - in other words, the precondition of due cautiousness. One can say that now it is acknowledged that the primary requirement for qualifying a behaviour as a prohibited act is surpassing the so called 'rules of caution'. ${ }^{9}$

Precautionary rules are understood as generally accepted rules of proceeding with a given good, aimed at securing this good against damage. Although the exact place of those rules in the structure of crime is still an issue that is subject to discussion, the prevailing position is that only a form of behaviour that we consider as not cautious or risky, not in line with the rules of conduct, can constitute an intentionally or unintentionally committed prohibited act and, subsequently, a crime. ${ }^{10}$ If someone acts cautiously in a given situation, for instance they drive at the minimum appropriate speed, they cannot breach any norm that would forbid them to (intentionally or unintentionally) act this way (the so-called sanctioned norm). And only the infringement of this norm would justify a criminal sanction (the use of a sanctioning norm). In common law, exercising due diligence may release one from strict liability. Analogously (as of course we do not have such liability in terms of criminal liability) in our system it is possible to counter charges of committing a criminal offence by referring to the precaution rules.

\footnotetext{
${ }^{6}$ See, e.g.: Kahan, Hoffman, Braman, Evans, Rachlinski (2012): 851-902.

7 E.g. Zawłocki (2013): 102.

8 Wróbel, Zoll (2013): 27, 189.

9 Wróbel, Zoll (2013): 174.

10 Byczyk (2016): 26; Królikowski (2010): 148-150.
} 
Those precaution rules have a prescriptive but not normative nature, in the sense that they are not norms of law. ${ }^{11}$ To some extent they are confirmed and included in legislative acts, but it is not those acts that are their source. They have not been catalogued anywhere, are open in nature, and are of diverse provenance. They follow non-legislative normative orders - moral, social, customary or religious norms, or relate to categories of 'common sense' based on observations of social life. ${ }^{12}$ Generally speaking, they rely on our current knowledge about the world, and need to be specified and adjusted to given conditions depending not only on objective aspects of the situation, but also - to some extent - on the personal characteristics of the acting person: we can expect different behaviour from someone with so-called 'special knowledge' than from an average person. ${ }^{13}$

What is very important in this regard is that in case of natural behaviour, those rules are mostly based on natural causation and our present, empirical understanding of the laws of nature, for example we know that a fast-moving car will not stop immediately and will hit and consequently damage another object standing in its way, hence we have a rule that forbids driving too fast, we know that if a bullet hits a person it will cause either their death or other serious damage, hence shooting bullets is basically considered incautious. One can say those rules are international and commonly shared by different societies, irrespective of their cultural setting. The laws of physics are universal. However, in the case of speech acts there nothing like natural causation. What we perceive as a speech act, what meaning we assign to this speech, and what perlocutionary effect it can induce, is only a derivative of our cultural experience. It is a product of the interpretations imposed on us, as members of certain interpretative communities. ${ }^{14}$ That is why the guidelines on what is cautious and what is hazardous in speech, indicating when a natural act of a person should be understood as an expression conveying a specific meaning, are based only on the practices and strategies adopted by a certain society with a particular cultural background. The rules of precaution are local, based on our cultural experience, and thus vary depending on the characteristics of the society.

One may say that the conclusion that culture determines how law functions is an obvious one - since law by itself is a product of culture. ${ }^{15}$ The creation of law is determined by culture and so of course is the application of legal provisions. What is important in this regard is that in the case of speech, including hate speech, it not only influences the understanding of law in books and the interpretation of given legal provisions, but also the process of establishing 'what happened' and whether there was a hazardous act.

In this respect, it is one thing to establish by means of interpretation if something has been expressed, and what has been said, and another thing

\footnotetext{
${ }^{11}$ Byczyk (2016): 236.

${ }^{12}$ Wróbel, Zoll (2013): 174.

${ }_{13}$ Królikowski (2010): 149-150, 174, 236.

${ }^{14}$ Demenko (2017): 27; see also Fish (1998): 141-162.

${ }^{15}$ Petrażycki (1968): 44.
} 
entirely to evaluate if what has been said infringes the local rules of precaution in a given situation. Calling someone a Jew might in certain societies be (rightly or wrongly) perceived as normal behaviour, falling within what is considered acceptable, whereas in another it might be seen as very inappropriate, and consequently as harmful. Even the use of words regarded as obscene must not necessarily always be considered as risky - if in a given interpretative community it is recognized as normal to use obscene words in certain situations. In this regard we must rely on what is customary and, consequently, what is socially acceptable.

In Poland it seems that customs allow a great deal - the language of contempt, hate speech in its broader meaning, is nowadays perceived as something almost immanent to public debate. There are numerous examples from social media where politicians and columnists use words which might not exactly qualify as hate speech in the strict sense, but are commonly considered as vulgar, insulting or slandering. To provide some examples: Janusz Palikot, former MP and deputy leader of the opposition party Civic Platform, called a journalist and former politician Magdalena Ogórek 'a whore' on Twitter; Radosław Sikorski, a former Minister of Defence and Foreign Affairs, told a member of the Polish Press Agency 'get lost whacko'; the conservative journalist Rafał Ziemkiewicz called the Mayor of Gdańsk 'a pathetic idiot' who 'supports those whose only purpose is to shit on Polish doormats and spit in the soup'; Senator Grzegorz Bierecki (from the ruling Law and Justice party) stated in an official speech that 'We will not stop until we have fully purged Poland of people who are not dignified enough to belong to our national community'; and the leader of the largest opposition party, Grzegorz Schetyna, said 'We must win...remove the Law and Justice locust from the healthy tree of our country.' 16

This 'environment' obviously influences the way we speak, and the meanings and senses we attribute to the words we use. Phrases originally characterized by contempt and carrying a negative emotional charge, such as: 'treacherous mugs' (an insult thrown from the parliamentary floor by Jarosław Kaczyński towards political opponents), and 'slaughter a pack' (statement by Radosław Sikorski during a convention), are now common in colloquial speech.

These are just some random examples of words spoken by high-ranking officials. Every day a new portion of that kind of language is served to society though the mass media - traditional and new, public and private. And they do not come from only a single political environment. The ongoing political dispute between the two largest political parties and their supporters (including commentators and journalists) seems to have been exempted from responsibility for speech acts. Insults and verbal abuse from one side seem to justify and excuse the same level of insults from the other. In this regard, one may of course note that there is a difference between hate speech and speech that is only impolite, tasteless or vulgar. It is in any case true, if we perceive hate speech in the strict sense of its meaning, if we consider hate speech as

16 See also Wiśniewska (2010): 249-262; Maszkowski (2020): 263-280. 
speech that is 'only' degrading and insulting, the line between unjust verbal discrimination and impoliteness becomes blurry. And we still need to bear in mind the broken window theory, which might be relevant in this context, to some extent - accustoming society with 'just' tasteless statements can lead to increasingly offensive language.

The deterioration of the language of public debate in Poland seems not to be restricted or hindered by the - in this regard crucial - concept of political correctness, understood as the principle of avoiding terms that could be considered as a manifestation of discrimination (against persons on the grounds of their race, nationality, religion, social origin or sexual orientation). ${ }^{17}$ This, of course, can be attributed to various reasons.

First of all, Poland after WW II was not a multicultural society in which minorities required protection. ${ }^{18}$ Thus, the concept of political correctness to safeguard their interests did not seem necessary. Secondly, in the Polish tradition of law and its application, the freedom of expression was valued much higher than other goods. In the period before the Partitions of Poland, it was an exclusive right of the gentry, but 'the gentry could use it in an almost unlimited way'. Freedom of public speaking was restricted only with regard to religious matters, and in the event of an attack on the honour and dignity of another nobleman, however even the monarch was not free from criticism there was a distinction between the monarch embodying the majesty of the Republic and the person of the monarch himself, who could be imperfect. In practice, members of parliament and regional assemblies had the right to speak in a completely free and unrestricted manner. ${ }^{19}$ This broadly understood right to freedom of expression was confirmed as libertas sentiendi by the Four-Year Sejm on 5 January $1791 .^{20}$ Freedom of speech, especially political expressions in the public arena, preserved its exceptional importance after Poland regained independence in 1918. Representatives of the intellectual elite of the time believed that political statements had to have guarantees of protection against restrictions, and politicians had to get used to what we would call today hate speech, in a broad sense. The regulations on freedom of expression 'were applied with great leniency to the authors of statements. Words addressed to citizens in the press, during rallies called by members of parliament in the election period or in the term of office, and finally from pulpits, were accusatory in tone and often served to discredit the opponent. ${ }^{21}$

This led us to a situation in which the language of the Polish public debate appears to be very open and free compared to Western countries. Thus, it is almost politically correct to be incorrect. As has already been mentioned, such

${ }^{17}$ For concepts of political correctness see, e.g. Huges (2010): 3-60.

${ }_{18}$ Due to the immigration process this cultural homogeneousness seems to be changing in the last years.

${ }^{19}$ Lewandowska-Malec (2013): 27-28.

${ }^{20}$ Mrozek (2013): 282. An important aspect contributing to the broad freedom of speech was also the lack of a single censorship office and conflicts of competence between the Krakow Academy (the first Polish University) and church authorities. This significantly weakened the importance of the printing privileges. Sobczak (2009): 55 .

${ }^{21}$ Lewandowska-Malec (2013): 18, 29-30. 
openness impacts our understanding of precaution in terms of speech acts and, in consequence, partly determines our understanding of criminal behaviour and hate speech that requires penal sanctions. ${ }^{22}$

This results in the peculiar permissiveness of the Polish investigative and judicial authorities towards hate speech. ${ }^{23}$ Though a definite thesis in this regard would require an in-depth case study, the experiences of various NGOs engaged in combating hate speech indicate that the application of the above-mentioned provisions of the criminal code leaves much to be desired. ${ }^{24}$ Judicial leniency towards acts that should be qualified as hate speech in the strict sense can be explained through the rules of precaution. Our caution about what might be said and expressed is just a conventional product, and the political, official culture of debate is transmitted into the rules also governing the private sphere. Put simply, if ministers are not prosecuted for using offensive and degrading language, because it is not perceived by society (including the judge) to be a hazardous act that can constitute a crime or petty offence, neither will average Joe Public. Consequently, it appears we enjoy more freedom of speech than the so-called traditional democracies in the sense that it is allowed to use a more offensive language and thus it is easier to express discriminating, biased attitudes. But this does not come from any deliberate valuation of freedoms (as in the US legal doctrine) or observance of human rights, but from a simple reluctance to any form of censorship, ensuing from our historic experience and from the lack of responsibility for spoken words, which according to Article 10(2) of the European convention on human rights, is a crucial element of the freedom of expression.

This is not only a specific Polish problem - if we looked into what is perceived as protected speech and as criminal speech by the societies and judicial authorities of various European countries, we would receive very different responses. Reaching the same or similar scope of criminalization, ensuring that the same behaviour constitutes an offence in all Member States, will not be possible without forming common standards and rules of cautiousness in regard to hazardous language, without cultural integration and the creation of common interpretative communities. First and foremost, it calls for the harmonization of social sensitivity. The question is: can this be achieved by legal means? The answer is yes and no. On the one hand, of course one cannot ignore the regulatory function of legal provisions as such. On the other hand, we must remember that any attempts at introducing restrictions that are not welcome or seem to be unnecessary in the society can be counterproductive. ${ }^{25}$ And in that regard speech is quite special - the best way to describe the restriction is to say exactly that what is forbidden, and thus to re-enact the undesired behaviour. If we want to inform somebody that saying ' $\mathrm{Mr}$ Jones is a thief' is penalized, we will have to say the forbidden words. However,

${ }^{22}$ As to the perception of hate speech in society see Bilewicz et al. (2014).

${ }^{23}$ See the 'incidents database' at <http://zglosnienawisc.otwarta.org/?lang=en $>$ administered by the NGO "Otwarta Rzeczpospolita” Association against Anti-Semitism and Xenophobia.

24 Ibidem.

25 Demenko (2019): 87-98; Cegła (2013): 57-70. 
this does not mean that we should do nothing. Legislative instruments need to be supported by non-legal means and education, in a broad sense. Some examples show that such an unforced change of attitude might occur. And here is a Polish example of this process - in the 1990s the use of the word 'Murzyn' was considered neutral. ${ }^{26}$ Today it is rather perceived as negative, as an equivalent of the English N-word, and is often replaced by the words 'czarny', 'czarnoskóry' (black), 'afroamerykański' (African-American) or 'afrykański' (African). This shift, of course, did not result from ay historical experience, but from certain general trends coming from outside. Not because of law, but because of a changing global perspective. Combating hate speech just by imposed legal means will not be effective, at least not in the long run. We should rather look into the reasons behind such speech and the local sensitivity, not forgetting that to some extent it will be justified to treat it also as kind of a security request. ${ }^{27}$

Anna Demenko

Adam Mickiewicz University, Poznań

suomessa@amu.edu.pl

https: / /orcid.org/0000-0002-6163-3739

Michat Urbańczyk

Adam Mickiewicz University, Poznań

mur@amu.edu.pl

https://orcid.org/0000-0003-4387-2848

Bilewicz, M., Marta Marchlewska, M., Soral, W., Winiewski M. (2014). Mowa nienawiści. Raport z badań sondażowych (Fundacja im. Stefana Batorego). Warsaw.

Byczyk, M. (2016). Normy ostrożności w prawie karnym. Poznań.

Cegła, A. (2013). Słowa niebezpieczne i niepożądane w przestrzeni społecznej. Etyka słowa a poprawność polityczna. Poradnik Językowy 10: 57-70.

Czykwin, E. (2007). Stygmat społeczny. Warsaw.

Demenko, A. (2017). Jak rozpoznać wypowiedź, gdy się ją widzi? Studia Prawnicze i Administracyjne 4: 21-27.

Demenko, A. (2019). Kontraproduktywność zakazu karnego, [in:] J. Piskorski (ed.), Istota, faktyczność i legitymizacja prawa karnego. Warsaw.

Fish, S. (1998). Change, [in:] S. Fish, Doing What Comes Naturally: Change Rhetoric, and the Practice of Theory in Literary and Legal Studies. Durham-London: 141-162.

Floyd, R. (2018). Parallels with the hate speech debate: the pros and cons of criminalising harmful securitising requests. Review of International Studies 44: 43-63.

Gliszczyńska A., Sękowska-Kozłowska, K., Wieruszewski, R. (2007). Monitorowanie treści rasistowskich i ksenofobicznych w polskiej prasie. Raport przygotowany na zlecenie MSWiA. Poznań. <http://otwarta.org/wp-content/uploads/2012/03/Polska-prasa-2007.pdf>.

${ }^{26}$ According to Katarzyna Kłosińska: 'The Polish name Murzyn derives from the Latin Maurus (which reached our language via Czech) meaning an inhabitant of North Africa, i.e. a person with a slightly darker complexion than us. In Roman times Europeans did not maintain contact with Africans with quite dark skin. This did not change until the colonial era; at that time they were called the Latin niger ("shiny black") - English Negro or French Negre. These words, used in English or French, are burdened with numerous connotations related to the heritage of colonialism and are therefore simply offensive.' Kłosińska rightly points out that 'one of the reasons for perceiving the name Murzyn as offensive is that its foreign language equivalents are indeed negative.' <https://sjp.pwn.pl/poradnia/haslo/Klopotliwy-Murzyn;17473.html>.

${ }^{27}$ Floyd (2018): 43-63; see also Molnar (2012): 183-197. 
Huges, G. (2013). Political Correctness: A History of Semantics and Culture. Wiley-Blackwell: $3-60$.

Kahan, D.M., Hoffman, D.A., Braman, D., Evans, D., Rachlinski, J.J. (2012). 'They Saw a Protest' cognitive illiberalism and the speech-conduct distinction. Stanford Law Review 64: 851-902.

Kowalski, S., Tulli, M. (2001). Mowa nienawiści. Raport. <http://or.icm.edu.pl/monitoring3.htm>.

Królikowski, M. (2010). Article 1, [w:] M. Królikowski, R. Zawłocki (eds.), Kodeks karny. Część ogólna. Volume 1. Warsaw: 148-150.

Lewandowska-Malec, I. (2013). Prawne i polityczne uwarunkowania wolności słowa w Rzeczypospolitej. Studia z Dziejów Państwa i Prawa 16: 9-39.

Łodziński, S. (2003). Problemy dyskryminacji osób należących do mniejszości narodowych i etnicznych w Polsce (polityka państwa, regulacje prawne i nastawienie społeczne. Warsaw.

Maszkowski, R. (2010). „Mowa nienawiści w Radiu Maryja (głos w dyskusji), [w:] A. Bodnar, A. Gliszczyńska-Grabias, R. Wieruszewski, M. Wyrzykowski (eds.), Mowa nienawiści a wolność słowa. Aspekty prawne i społeczne. Warsaw: 263-280.

Molnar, P. (2012). Responding to "hate speech" with art, education, and the imminent danger test, [w:] M. Herz, P. Molnar (eds.), The Content and Context of Hate Speech Rethinking Regulation and Responses. Cambridge-New York: 183-197.

Mrozek, J. (2013). Prawne źródła wolności słowa w Polsce. Studia Prawnoustrojowe 22: 281-287.

Petrażycki, L. (1968). Wstęp do nauki polityki prawa. Warsaw.

Rogalska, E., Urbańczyk, M. (2017). Złożoność zjawiska mowy nienawiści w pozaprawnym aspekcie definicyjnym. Acta Universitatits Wratislaviensis 2: 117-135.

Schauer, F. (2015). On the distinction between speech and action. Emory Law Journal 65: 427454.

Sobczak, J. (2009). Dzieje prawa prasowego na ziemiach polskich. Poznań.

Wiśniewska, P. (2010). Język nienawiści w ustach polityków polskich. Analiza zagadnienia na bazie internetowych wydań środków komunikacji społecznej - pod koniec pierwszego dziesięciolecia XXI wieku, [in:] A. Bodnar, A. Gliszczyńska-Grabias, R. Wieruszewski, M. Wyrzykowski (eds.), Mowa nienawiści a wolność słowa. Aspekty prawne i społeczne. Warsaw: 249-262.

Wróbel, W., Zoll, A. (2013). Polskie prawo karne. Część ogólna. Cracow.

Zawłocki, R. (2013). Przestępstwo i jego struktura. Pojęcie przestępstwa, [w:] R. Dębski (ed.), System prawa karnego. Nauka o przestępstwie. Zasady odpowiedzialności. Warsaw: 36-133.

\section{POLITICALLY CORRECT HATE SPEECH}

\section{$\mathrm{Su} \mathrm{m} \mathrm{m}$ a r y}

In the paper we discuss the reasons behind a specific permissiveness of the Polish judicial authorities with regard to hate speech. Hate speech is criminalized by various provisions of the Polish Criminal Code. But as conducted surveys and statistics show, these regulations do not seem to be used adequately. The acceptance of hate speech does not necessarily result from the fact that we are a less tolerant society, but also to a large extent, from the fact that the scope of what is allowed to be said, especially publicly, is in Poland very broad. Paradoxically, it seems that in this 'new democracy' there is more freedom of speech than in Western countries, where political correctness plays a very important role in public and social life. The lack of responsibility that goes with freedom of speech and of boundaries on what might be expressed in public, the scurrilous language used also by high-ranking officials, influence the rules of socially acceptable behaviour. These rules also influence the scope of what is considered criminal behaviour. When tackling the problem of the acceptance of hate speech, it is also very important to remember that legal acts, especially criminal law, might not necessarily be the best way to change the attitudes in a society. Restrictions on freedom of speech might not only have a freezing effect but also be counterproductive - that which it is prohibited to say tends to be said more. The problem is to strike the right balance between those two possible outcomes.

Keywords: hate speech; political correctness; criminal law; freedom of speech; rules of precaution 
